\title{
Interpopulational variation in costs of reproduction related to pregnancy in a viviparous lizard
}

\author{
K. ITONAGA ${ }^{1}$, A. EdWARds ${ }^{1,2}$, E. WAPSTRA ${ }^{1}$ and S.M. Jones ${ }^{1}$ \\ ${ }^{1}$ School of Zoology, University of Tasmania, Private Bag 5, Hobart, TAS 7001, Australia
}

Received 25 October 2010, accepted 6 June 2012

\begin{abstract}
Interpopulational variation in reproductive costs may affect variation in life history traits including reproductive investment (i.e. clutch mass relative to either maternal body mass or length). While the relationships between reproductive investment and costs of reproduction, especially costs to mobility, have been well studied in squamate reptiles, how these costs relate to investment and explain patterns within and between populations is not always straightforward. In the present study, we examined the relationship between reproductive investment and costs of reproduction (gravid and postpartum sprint speeds and maternal postpartum body condition) in two populations of a viviparous skink, Pseudemoia entrecasteauxii living in different habitat types. We found that costs of reproduction (i.e. impact on gravid and postpartum sprint speeds) depended on the interaction between relative reproductive burden (RRB) and population. There was no link between relative clutch mass (RCM) and maternal sprint speeds. Maternal postpartum body condition was not related to either RRB or RCM for either population. Gravid females living in the open habitat population showed significantly slower sprint speed compared with the same females immediately postparturition, and other gravid females living in a closed habitat population. Such females are likely to experience a higher cost of reproduction in terms of changes in sprint speed as well as exposure to predators and may show a behavioural shift to crypsis in order to compensate for locomotor impairment and to reduce the risk of predation. We suggest that factors which relate to costs of reproduction (i.e. sprint speeds) are complex and may involve multiple factors such as reproductive investment and habitat characteristics.
\end{abstract}

KEY WORDS: costs of reproduction, interpopulational variation, performance ability, Pseudemoia entrecasteauxii, reproductive investment.

\section{INTRODUCTION}

Trade-offs between reproduction and survival are important determinants of lifehistory traits (Williams 1966; Hillesheim \& StEARns 1992; REZnicK et al. 2000).

${ }^{2}$ Corresponding author: Ashley Edwards, School of Zoology, University of Tasmania, Private Bag 5, Hobart, TAS 7001, Australia (E-mail: Ashley.Edwards@utas.edu.au). 
Natural selection shapes life history characteristics such as reproductive traits (e.g. clutch size, age and size at maturity) in order to enhance fitness in different environments (RofF 1992). For any animal, the costs of reproduction are important factors influencing further reproduction and survival (EKMAN \& ASKENMO 1986). Although such costs have proven difficult to measure (REZNICK 1992; OLSSON et al. 2000, 2001), variation between populations has been documented in both invertebrates (e.g. CARroll 1993; Frankino \& Juliano 1999) and vertebrates (e.g. TofT et al. 1984; SINERVO et al. 1991; WAPSTRA \& O'REILLY 2001). The costs of reproduction can vary due to physiological factors such as reproductive status (BERGLUND \& RosEQVIST 1986; DeMarco \& Guillette 1992; MoE et al. 2002) and ecological factors such as predation risk (BAUWENS \& THOEN 1981; BRODIE 1989; SCHWARZKOPF \& SHINE 1992). Understanding how costs of reproduction vary is important in explaining intraspecific variation in life history strategies and, specifically, reproductive investment (i.e. clutch or litter mass relative to either maternal body mass or length).

Among the potential costs of reproduction, impairment of locomotor performance in pregnant animals has been emphasised in a variety of viviparous taxa (CUTHill \& Houston 1997). This is because the impacts of pregnancy on locomotor performance can constrain ecological activities such as foraging and predator avoidance (e.g. BELL 1980; HUSAK 2006). Understanding how reproduction incurs a cost through, for example, a reduction in locomotor performance is not straightforward. However, it is vital for an understanding of the nature of the trade-off between costs (i.e. survival) and benefits (i.e. reproduction) and how selection will act on specific aspects of reproductive investment. For example, in reptiles, relative clutch mass (RCM: the clutch mass relative to the postpartum female mass) is the dominant measure of reproductive investment (SHINE 1980). Relative clutch mass is negatively related to gravid sprint speed in some species (e.g. Nannoscincus maccoyi, Pseudemoia entrecasteauxii, Niveoscincus coventryi and Eulamprus tympanum SHINE 1980; Lacerta vivipara VAN DAMmE et al. 1989) but not others (e.g. Thamnophis ordinoides BRODIE 1989; Plestiodon laticeps CoOper et al. 1990; Sceloporus occidentalis SINERVo et al. 1991). Relative reproductive burden (RRB: the clutch mass relative to female snout-vent length: SVL) is another relevant measure of reproductive investment in reptiles (SINERVO et al. 1991) because morphological traits (e.g. body length) potentially affect sprint speed (CLEMENTE et al. 2009). Relative reproductive burden is negatively related to gravid sprint speed in some species, although RCM may not be an influence on their gravid sprint speed (e.g. S. occidentalis SINERVO et al. 1991; Niveoscincus ocellatus WAPSTRA \& O'REILLY 2001).

In addition to the negative effects of physical factors such as RCM and RRB on sprint speed, physiological changes related to pregnancy can also reduce gravid sprint speed. Surprisingly, these negative effects may not be proportional to RCM and RRB (BAUWENS \& THOEN 1981; Olsson et al. 2000). For example, sprint speed in gravid animals can be reduced by the need to maintain a body temperature optimal for embryogenesis (e.g. S. jarrovi BEUCHAT 1988; S. grammicus ANDREWs et al. 1997). In contrast, pregnancy does not appear to reduce gravid sprint speed in other species (e.g. S. merriami HUEY et al. 1990), and may actually enhance sprint speed in some (e.g. Lampropholis guichenoti QuALls \& SHINE 1997). Presumably, these variations reflect species-specific differences in features such as levels of reproductive investment and also selection pressures such as predation (COOPER et al. 1990; OLsson et al. 2000).

The costs related to reproductive investment in viviparous reptiles may be incurred not only during gestation, but also after parturition (COx 2006). Similarly, 
these costs after laying eggs have been documented in oviparous reptiles (LANDWER 1994; Cox \& CALSBEEK 2010). For example, some viviparous reptiles (e.g. N. microlepidotus OlsSON et al. 2000; L. vivipara LE GALLIARD et al. 2003) experience impaired sprint speed during the short period after parturition. This impairment may be related to maternal muscle mass lost during gestation due to protein catabolism of maternal tissue for support of embryonic development (LOURDAIS et al. 2004). Furthermore, a large investment during a current reproductive effort may result in reduced body condition at parturition, potentially affecting future reproductive efforts and even survival rates in the following year (AVERY 1970; BONNET et al. 1999, 2002). In viviparous reptiles displaying a high degree of placentotrophy, in which embryos are nourished primarily by maternal nutrient transfer across the placenta (especially in annual breeders), impaired maternal postpartum body condition may be a considerable cost of reproduction (Avery 1970; WiLson \& Booth 1998; BonNet et al. 1999, 2002). This is because females must allocate significantly more energy to embryonic development during gestation than do viviparous reptiles displaying predominantly lecithotrophy, in which embryos are nourished primarily by yolk laid down prior to gestation (THOMPSON et al. 2000). Consequently, females of highly placentotrophic species may incur greater loss to body condition from current reproduction for a significant time after birth.

Even within a reptilian species, the impacts of pregnancy on the costs of reproduction are also not always consistent between populations (e.g. L. guichenoti QUALLS \& SHINe 1997; Lerista bougainvillii QuALLS \& SHINe 1998). This may be because selective pressures, such as predation pressure, vary between habitats (SNELL et al. 1988; WAPSTRA \& O’REILlY 2001; PUNZO 2007), and selective pressures may also affect interpopulational variation in life history traits including reproductive investment (WAPSTRA \& O'REILLY 2001). However, how such variation in life history traits and selection shape reproductive investment through the costs of reproduction remain to be fully understood. The aim of the present study was to understand how reproductive investment and costs of reproduction co-vary between populations. We investigated the relationship between reproductive investment and costs of reproduction during pregnancy and immediately postpartum in two populations of a highly placentotrophic lizard, $P$. entrecasteauxii, living in different habitat types. During pregnancy, and immediately post parturition, we assessed the relationships between RCM, RRB and sprint speed, and immediately postpartum, the relationships between reproductive investment, sprint speed and maternal body condition. We tested whether the costs of reproduction related to reproductive investment varied between populations.

\section{MATERIALS AND METHODS}

Study species

Southern grass skinks, P. entrecasteauxii, are small, ground-dwelling lizards. Females rarely exceed $60 \mathrm{~mm}$ SVL, and males rarely exceed $50 \mathrm{~mm}$ (HUTCHINSON et al. 2001; ITONAGA et al. 2011, 2012a). They are restricted to the south-eastern Australian mainland, Tasmania and the Bass Strait Islands (BROWN 1988). In Tasmania, they are common in grassy habitats over wide climatic and geographical ranges (sea level to about 1000 m) (WILSON \& KNOWLES 1988; CogGer 1992). We chose them as a study species because: (1) they live in a wide range of habitats, and so may show interpopulational differences in life history traits including reproductive investment; and (2) they are a viviparous reptile utilising a high degree of placentotrophy (THOMPSON et al. 2000; ITONAGA et al. 2012b), so that physiological impacts of pregnancy on costs of reproduction may be expected to be significant. 


\section{Capture sites and husbandry}

Gravid P. entrecasteauxii were collected by mealworm 'fishing' in January 2005 at two sites near Orford in Tasmania, Australia. At each site, we took several photos at typical basking sites of $P$. entrecasteauxii using a digital camera with a fisheye lens to estimate levels of canopy cover. Our study sites were homogenous habitats and canopy cover was calculated by using Gap Light Analyser Version 2.0. We defined two distinct habitat types: Pulchella Nursery $\left(42^{\circ} 36^{\prime} \mathrm{S}, 147^{\circ} 40^{\prime} \mathrm{E}\right.$; altitude $198 \mathrm{~m}$, average canopy openness $55.23 \%(\mathrm{n}=3)$ ) was defined as an "open habitat" (i.e. the main canopy cover was short grass). Most basking sites at this location were available throughout the whole day and the vegetation was dominated by tussock grasses (Poa labillardierei). The substrate consisted mainly of open ground (red soil) with a few small rocks. We defined The Three Thumbs Reserve ( $42^{\circ} 36^{\prime} \mathrm{S}, 147^{\circ} 52^{\prime} \mathrm{E}$; altitude $426 \mathrm{~m}$, average canopy openness $31.65 \%$ $(n=5))$ as a "closed habitat" (i.e. the main canopy cover was tall trees). This site constituted a complex environment of mixed substrate and vegetation types, and basking site availability changed dramatically throughout the day. This site was predominantly dry sclerophyll (Eucalyptus amygdalina) forest. The most common understorey plants were sagg plant (Lomandra longifolia), cheese berry (Cyathodes glauca) and heath (Epacris tasmanica).

Nine late stage pregnant females were collected from the open habitat and 25 late stage pregnant females were collected from the closed habitat. Each lizard was housed individually in a plastic terrarium $(30 \times 20 \times 10 \mathrm{~cm})$ until parturition occurred (within a week). Each terrarium contained paper pellets as substrate, two terracotta saucers as basking sites, and a plastic plate as a shelter. Water, supplemented with multi-vitamins, was available ad libitum. Lizards were fed human baby food (HEINZ ${ }^{\circledR}$ pear flavour) and mealworms and held under a 12 L:12 D photoperiod regime (lights on 7 a.m. to 7 p.m.). The temperature in the room was kept at $12{ }^{\circ} \mathrm{C}$; a $25 \mathrm{w}$ bulb above each cage provided a temperature gradient for thermoregulation $\left(12-40^{\circ} \mathrm{C}\right)$.

\section{Sprint trials}

Prior to the sprint trials, all lizards were measured (SVL $\pm 0.01 \mathrm{~mm}$ ) and weighed $( \pm 0.001 \mathrm{~g})$ and each lizard was held in a petri dish in a water bath $\left(28 \pm 1{ }^{\circ} \mathrm{C}\right)$ for $30 \mathrm{~min}$ so that its body temperature was raised to the species' optimum of $28{ }^{\circ} \mathrm{C}$ for sprinting (Melville 1998). All captive lizards were sprinted twice: approximately 1 week prior to parturition; and again within $24 \mathrm{hr}$ after parturition. A straight racetrack ( $160 \mathrm{~cm}$ long, $8 \mathrm{~cm}$ wide) was heated to $28 \pm$ $1{ }^{\circ} \mathrm{C}$. Melville \& SWAin (2003) considered that $50 \mathrm{~cm}$ is representative of a typical distance over which small skinks would sprint to escape predation in the field; therefore sprint time along the track was recorded by three equally spaced $(50 \mathrm{~cm})$ infrared light beams. The fastest sprint speed over a $50 \mathrm{~cm}$ distance was taken as the maximum sprint speed (e.g. Melville \& SWAIN 2003). Lizards were encouraged to run by occasional gentle taps on the tail using a soft paint brush. In each trial, lizards were run along the racetrack twice without any interval between sprint trials. A previous study of endurance in small skinks (CHAPPLE \& SWAIN 2002) provides evidence that any effects of fatigue on sprint trials are negligible. At the conclusion of sprint trials, all animals, including neonates, were released at their site of capture.

\section{Reproductive investment and maternal postpartum body condition}

At birth, all neonates were weighed $( \pm 0.001 \mathrm{~g})$ and clutch mass was calculated as the sum of the masses of all offspring within each clutch. Relative clutch mass (RCM) was calculated as clutch mass/maternal postpartum body mass immediately after parturition (SHINE 1980). In general, clutch mass and maternal SVL are positively correlated (SINERVo et al. 1991). In the present study, this assumption was supported overall $(r=0.5112, P<0.01)$ and also in each population. Therefore, in our analyses, we used residuals (i.e. relative reproductive burden (RRB)), which were generated from a regression analysis of all values for clutch mass and maternal SVL (SINERVO et al. 1991; WAPSTRA \& O'REILlY 2001). Maternal postpartum body condition within each population 
was calculated as the residual of the regression from log-transformed postpartum mass and SVL (because of the allometry of body size) (e.g. CADBY et al. 2010; ITONAGA et al. 2012a).

\section{Statistical analyses}

Differences in maternal SVL, clutch mass, RCM and RRB between sites were analysed using independent T-tests. There was no relationship between sprint speed and maternal SVL in either population. Therefore, two-way repeated measures ANOVAs were used to examine the effects of reproductive condition (gestation and the period immediately postparturition), population, reproductive investment (i.e. RCM or RRB) and the interaction between them on sprint speed. Linear regression analyses were used to examine the relationships between reproductive investment (i.e. RCM and RRB) and maternal postpartum body condition, within each population. All analyses were performed using SAS ${ }^{\circledR} 9.1$ for Windows. Significance was taken at $\alpha<0.05$ for all tests.

\section{RESULTS}

There were distinct differences in reproductive traits between populations. Clutch mass (independent T-test: $\mathrm{t}=2.387, \mathrm{df}=32, P<0.05)$ and relative clutch mass $(\mathrm{RCM})$ (independent T-test: $\mathrm{t}=3.807, \mathrm{df}=32, P<0.001$ ) were significantly higher in females living in an open habitat than in females living in a closed habitat, although there was no significant difference in maternal SVL between populations from these habitat types (Table 1). There was also no difference in relative reproductive burden (RRB) between the populations.

Regarding within-subject effects, in the case of RCM, the effect of reproductive condition (i.e. gestation or postparturition) on sprint speed was not significant. In addition, no factors, or their interactions, significantly affected sprint speed. However, we found that in the case of RRB, the effect of reproductive condition was significant

\section{Table 1.}

Characteristics of female Pseudemoia entrecasteauxii including snout-vent length, clutch mass, relative clutch mass, postpartum mass, gravid and postpartum sprint speeds, and postpartum body condition (Student residual of the regression from log-transformed postpartum mass and snout-vent length) from open $(n=9)$ and closed $(n=25)$ habitat types. Values are means $\pm \mathrm{SE}$, ${ }^{*}$ : significantly $(P<0.05)$ different between sites, $\bullet$ : significantly $(P<0.05)$ different in gravid versus postpartum females.

\begin{tabular}{|c|c|c|}
\hline Female characteristics & Open habitat & Closed habitat \\
\hline Snout-vent length (mm) & $48.000 \pm 0.135$ & $46.436 \pm 0.054$ \\
\hline Clutch mass (g) & $0.614 \pm 0.067$ & $0.426 \pm 0.042^{*}$ \\
\hline $\mathrm{RCM}$ & $0.377 \pm 0.025$ & $0.255 \pm 0.020^{*}$ \\
\hline Postpartum mass (g) & $1.637 \pm 0.148$ & $1.654 \pm 0.054$ \\
\hline Gravid speed $\left(\mathrm{m} \mathrm{sec}^{-1}\right)$ & $0.217 \pm 0.021$ & $0.275 \pm 0.018^{*}$ \\
\hline Postpartum speed $\left(\mathrm{m} \mathrm{sec}^{-1}\right)$ & $0.316 \pm 0.026$ & $0.296 \pm 0.015$ \\
\hline Postpartum body condition (residual) & $0.0001 \pm 0.437$ & $-0.030 \pm 0.218$ \\
\hline
\end{tabular}


(two way repeated measures (RM) ANOVA: $F_{1,30}=8.93, P<0.01$ ) and the interaction between reproductive condition, RRB and population significantly affected sprint speed (two way RM ANOVA: $F_{1,30}=4.31, P<0.05$ ). This means that the effect of reproductive condition on sprint speed was dependent on the interaction between RRB and population. During gestation, mean sprint speed of females living in the open habitat was slower than that of females living in the closed habitat (two way RM ANOVA: $\left.F_{1,30}=4.09, P=0.05\right)$. However, there was no difference in postpartum sprint speed between the two populations. Additionally, for females living in the open habitat, the mean sprint speed of gravid females was significantly slower $(32 \%)$ than for the same females immediately postparturition (post-hoc paired T-test: $\mathrm{t}=2.825, \mathrm{df}=8, P=$ 0.022 ). In females living in the closed habitat, however, there was no significant difference in mean sprint speed between gravid females and the same females immediately postparturition (Table 1). Maternal postpartum body condition of females living in each habitat population are shown in Table 1 . We found that maternal postpartum body condition was not related to either RCM or RRB for either population.

\section{DISCUSSION}

We demonstrated that costs of reproduction (i.e. gravid and postpartum sprint speeds) depended on the interaction between relative reproductive burden (RRB) and the population of origin, despite the fact that there was no difference in RRB between populations. While we did not find any effects of relative clutch mass (RCM) on either gravid or postpartum sprint speeds, there was a difference in RCM between populations. We found that neither RRB nor RCM were costs of reproduction in terms of postpartum maternal body condition in a viviparous reptile.

Our populations come from very different habitats and we found that only females living in an open habitat significantly reduced their mean sprint speed while gravid. Relative reproductive burden may affect gravid sprint speed because a large clutch may interfere anatomically with the ability of females, especially small females, to run fast (SINERVO et al. 1991; WAPSTRA \& O'REILLY 2001). Reduction in sprint speed may be critical for survival in females living in an open habitat, even though the effect of RRB on gravid sprint speed was small. In a concurrent study at the same sites, K. ITONAGA (unpublished data) found that lizards living in an open habitat showed greater vigilance (measured as approach distance) and stayed closer to refuges compared with lizards living in a closed habitat. Similarly, other studies have documented variation in behaviour between habitats in response to predators (e.g. QUALLS \& SHINE 1997; WAPSTRA \& O'REILlY 2001; PUnzo 2007). Open habitats should favour the evolution of traits that increase predator avoidance, such as greater sprint speed (SNELL et al. 1988; Punzo 2007; Gifford et al. 2008). Therefore, female P. entrecasteauxii living in an open habitat may shift anti-predatory behaviour from sprinting to crypsis during gestation to compensate for locomotor impairment. Such behavioural shifts related to heavy body mass, including pregnancy, have been observed in several taxa including reptiles (e.g. BAUWENS \& THOEN 1981; COOPER et al. 1990; KATHERINE et al. 2009).

Utilisation of crypsis may affect the measurements of gravid sprint speed because animals which use crypsis tend to run only short distances before stopping and remaining immobile (PIANKA \& VITT 2003). This may explain why we detected slower gravid sprint speed in females living in an open habitat compared with both the same females immediately postparturition, and other gravid females living in a closed habitat. The extensive basking opportunities available at this open habitat site, combined with a 
sit-and-wait foraging strategy with abundant mobile prey items such as butterflies and grasshoppers (K. ITONAGA personal obs), may allow $P$. entrecasteauxii to gain an advantage from crypsis during gestation. A behavioural shift from crypsis back to sprinting as a predator avoidance strategy occurred within the first $24 \mathrm{hr}$ after parturition because immediately postpartum sprint speed of females living in an open habitat was significantly increased compared with the same females during pregnancy.

We did not find a significant relationship between RCM and either gravid or postpartum sprint speeds, although SHINE (1980) has previously reported a negative relationship between RCM and gravid sprint speed in P. entrecasteauxii. However, there were differences in mean SVL and habitat between the two studies (i.e. $46-48 \mathrm{~mm}$ mean SVL in the Tasmania populations and $56 \mathrm{~mm}$ mean SVL in the Australian main land population in SHINE 1980). Therefore, we suggest that morphological and habitat (e.g. predation pressure and habitat structure) differences between the two studies may explain the different findings (see also as an example SINERVO et al. 1991).

We did not find any evidence of impaired maternal postpartum body condition related to reproductive investment in either population. This suggests that $P$. entrecasteauxii may be able to simultaneously maintain their own body condition and allocate energy for embryonic development during gestation (ITONAGA et al. 2012a; also see CADBY et al. 2011). Indeed, WAPSTRA \& SWAIN (2001) found that abdominal fat body mass in a sympatric viviparous reptile, $N$. ocellatus, was higher at the end of pregnancy than in early and mid pregnancy, despite the fact that they also provide relatively large placental contributions to embryonic nutrition (THOMPSON et al. 2000). In addition, our study species does not reduce feeding rates during gestation (SHINE 1980).

In summary, the cost of reproduction measured as sprint speed varied between reproductive states (i.e. pregnancy and postpartum) and depended on the interaction between RRB and population. Relative clutch mass did not affect either gravid or postpartum sprint speeds, although a previous study (SHINE 1980) has found a link between RCM and gravid sprint speed. Therefore, we suggest that factors which relate to costs of reproduction (i.e. sprint speeds) are complex and may involve interpopulational variation in reproductive investment (e.g. RCM and RRB), behaviour, habitat characteristics and morphology.

\section{ACKNOWLEDGEMENTS}

Natalia Atkins and Jemina Stuart-Smith aided in the collection of lizards. EW thanks the Australian Research Council for support. This research was conducted under Animal Ethics Permit A0008145 from the University of Tasmania. A permit for work at the Pulchella Nursery and at The Three Thumbs Reserve was issued by the Department of Primary Industries, Water and Environment (Permit No. FA 04188).

\section{REFERENCES}

Andrews R.M., Mendez de la CRuz F.R. \& Villagran Santa CRuz M. 1997. Body temperatures of female Sceloporus grammicus: thermal stress or impaired mobility? Copeia (1): 108-115.

AVERY R.A. 1970. Utilization of caudal fat by hibernating common lizards, Lacerta vivipara. Comparative Biochemistry and Physiology 37: 119-121. 
BAUWENS D. \& THOEN C. 1981. Escape tactics and vulnerability to predation associated with reproduction in the lizard Lacerta vivipara. Journal of Animal Ecology 50: 733-743.

BELL G. 1980. The costs of reproduction and their consequences. The American Naturalist 116: 45-76.

Berglund A. \& RosenQvist G. 1986. Reproductive cost in the prawn Palaemon adspersus: effects on growth and predator vulnerability. Oikos 46: 349-354.

Beuchat C.A. 1988. Temperature effects during gestation in a viviparous lizard. Journal of Thermal Biology 13: 135-142.

Bonnet X., Lourdais O., Shine R. \& Naulleau G. 2002. Reproduction in a typical capital breeder: costs, currencies, and complications in the aspic viper. Ecology 83: 2124-2135.

Bonnet X., Naulleau G., Shine R. \& Lourdais O. 1999. What is the appropriate timescale for measuring costs of reproduction in a 'capital breeder' such as the aspic viper? Evolutionary Ecology 13: 485-497.

BRODIE E.D. III 1989. Behavioral modification as a means of reducing the cost of reproduction. The American Naturalist 134: 225-238.

BRown G. 1988. The diet of Leiolopisma entrecasteauxii (Lacertilia: Scincidae) from south-western Victoria, with notes on its relationship with the reproductive cycle. Australian Wildlife Research 15: 605-614.

CADBY C.D., Jones S.M. \& WAPSTRA E. 2010. Are increased concentrations of maternal corticosterone adaptive to offspring? A test using a placentotrophic lizard. Functional Ecology 24: 409-416.

CADBy C.D., JonEs S.M. \& WAPSTRA E. 2011. Potentially adaptive effects of maternal nutrition during gestation on offspring phenotype of a viviparous reptile. Journal of Experimental Biology 214: 4234-4239.

CARROLL S.P. 1993. Divergence in male mating tactics between two populations of the soapberry bug: I. guarding versus nonguarding. Behavioral Ecology 4: 156-164.

Chapple D.G. \& SWAin R. 2002. Effect of caudal autotomy on locomotor performance in a viviparous skink, Niveoscincus metallicus. Functional Ecology 16: 817-825.

Clemente C.J., Thompson G.G. \& Withers P.C. 2009. Evolutionary relationships of sprint speed in Australian varanid lizards. Journal of Zoology 278: 270-280.

Cogger H.G. 1992. Reptiles and Amphibians of Australia, 5th ed. NSW: Reed Books, Chatswood.

Cooper W.E. JR, VitT L.J., Hedges R. \& Huey R.B. 1990. Locomotor impairment and defense in gravid lizards (Eumeces laticeps): behavioral shift in activity may offset costs of reproduction in an active forager. Behavioral Ecology and Sociobiology 27: 153-157.

Cox R.M. 2006. A test of the reproductive cost hypothesis for sexual size dimorphism in Yarrow's spiny lizard Sceloporus jarrovi. Journal of Animal Ecology 75: 1361-1369.

Cox R.M. \& CALSBEEK R. 2010. Severe costs of reproduction persist in anolis lizards despite the evolution of a single-egg clutch. Evolution 64: 1321-1330.

Cuthill I. \& Houston A. 1997. Managing time and energy, pp. 97-120. In: Krebs J.R. \& Davies N.B., Eds. Behavioural ecology - an evolutionary approach. Cambridge: Blackwell Science.

Demarco V. \& Guillette L.J. JR 1992. Physiological cost of pregnancy in a viviparous lizard (Sceloporus jarrovi). Journal of Experimental Zoology 262: 383-390.

EKMAN J. \& ASKENMO C. 1986. Reproductive cost, age-specifics survival and a comparison of the reproductive strategy in two European tits (Genus Parus). Evolution 40: 159-168.

FrANKINO W.A. \& JULIANO S.A. 1999. Costs of reproduction and geographic variation in the reproductive tactics of the mosquito Aedes triseriatus. Oecologia 120: 59-68.

Gifford M.E., Herrel A. \& MAHLER D.L. 2008. The evolution of locomotor morphology, performance, and anti-predator behaviour among populations of Leiocephalus lizards from the Dominican Republic. Biological Journal of the Linnean Society 93: 445-456.

Hillesheim E. \& Stearns S.C. 1992. Correlated responses in life-history traits to artificial selection for body weight in Drosophila melanogaster. Evolution 46: 745-752.

Huey R.B., Dunham A.E., Overall K.L. \& Newman R.A. 1990. Variation in locomotor performance in demographically known populations of the lizard Sceloporus merriami. Physiological Zoology 63: 845-872. 
HUSAK J.F. 2006. Do female collared lizards change field use of maximal sprint speed capacity when gravid? Oecologia 150: 339-343.

Hutchinson M., Swain R. \& Driessen M. 2001. Snakes and lizards of Tasmania. University of Tasmania: Fauna of Tasmania Committee.

ITONAGA K., Jones S.M. \& WAPSTRA E. 2011. Effects of variation in maternal carotenoid intake during gestation on offspring innate immune response in a matrotrophic viviparous reptile. Functional Ecology 25: 1318-1326.

Itonaga K., Jones S.M. \& WAPSTRA E. 2012a. Do gravid females become selfish? Female allocation of energy during gestation. Physiological and Biochemical Zoology 85: 231-242.

ITONAGA K., WAPSTRA E. \& JONES S.M. 2012b. A novel pattern of placental leucine transfer during mid to late gestation in a highly placentotrophic viviparous lizard. Journal of Experimental Zoology (B) 318: 308-315.

KATHERINE A.J., JOHN R.K. \& MARK J.W. 2009. Heavier birds react faster to predators: individual differences in the detection of stalking and ambush predators. Behavioral Ecology and Sociobiology 63: 1319-1329.

LANDWER A.J. 1994. Manipulation of egg production reveals costs of reproduction in the tree lizard (Urosaurus ornatus). Oecologia 100: 243-249.

Le Galliard J., Le Bris M. \& Clobert J. 2003. Timing of locomotor impairment and shift in thermal preferences during gravidity in a viviparous lizard. Functional Ecology 17: 877-885.

Lourdais O., Brischoux F., DeNardo D. \& Shine R. 2004. Protein catabolism in pregnant snakes (Epicrates cenchria maurus, Boidae) compromises musculature and performance after reproduction. Journal of Comparative Physiology (B-Biochemical Systemic and Environmental Physiology) 174: 383-391.

Melville J. 1998. The evolution of locomotory mode in the lizard genus Niveoscincus. Unpublished Ph.D. Thesis, University of Tasmania, Hobart.

MELVILlE J. \& SWAIN R. 2003. Evolutionary correlations between escape behaviour and performance ability in eight species of snow skinks (Niveoscincus; Lygosominae) from Tasmania. Journal of Zoology, London 261: 79-89.

Moe B., Langseth I., Fyhn M., Gabrielsen G.W. \& Bech C. 2002. Changes in body condition in breeding kittiwakes Rissa tridactyla. Journal of Avian Biology 33: 225-234.

Olsson M., ShInE R. \& BAK-Olsson E. 2000. Locomotor impairment of gravid lizards: is the burden physical or physiological? Journal of Evolutionary Biology 13: 263-268.

OlsSOn M., WAPSTRA E. \& SHINE R. 2001. Costs of reproduction in a lizard species: a comparison of observational and experimental data. Oikos 93: 121-125.

PiANKA E.R. \& VitT L.J. 2003. Lizards. California: University of California Press.

PUNZO F. 2007. Sprint speed and degree of wariness in two populations of whiptail lizards (Aspidoscelis tesselata) (Squamata Teiidae). Ethology Ecology \& Evolution 19: 159-169.

QuAlls C.P. \& SHINE R. 1997. Geographical variation in 'costs of reproduction' in the scincid lizard Lampropholis guichenoti. Functional Ecology 11: 757-763.

QUALLS C.P. \& SHINE R. 1998. Costs of reproduction in conspecific oviparous viviparous lizards, Lerista bougainvillii. Oikos 82: 539-551.

REZNICK D. 1992. Measuring reproductive costs: response to partridge. Trends in Ecology \& Evolution 7: 134.

ReZnick D., NunNey L. \& Tessier A. 2000. Big houses, big cars, superfleas and the costs of reproduction. Trends in Ecology \& Evolution 15: 421-425.

RofF D.L. 1992. The evolution of life histories theory and analysis. New York: Chapman \& Hall.

SCHWARZKOPF L. \& SHINE R. 1992. Costs of reproduction in lizards: escape tactics and susceptibility to predation. Behavioral Ecology and Sociobiology 31: 17-25.

SHINE R. 1980. 'Costs' of reproduction in reptiles. Oecologia 46: 92-100.

Sinervo B., Hedgers R. \& Adolph S.C. 1991. Decreased sprint speed as a cost of reproduction in the lizard Sceloporus occidentalis: variation among populations. Journal of Experimental Biology 155: 323-336.

SNell H.L., Jennings R.D., SNell H.M. \& Harcount S. 1988. Intrapopulation variation in predator-avoidance performance of Galapagos lava lizards: the interaction of sexual and natural selection. Evolutionary Ecology 2: 352-369. 
Thompson M.B., Steward J.R. \& SPEAKE B.K. 2000. Comparison of nutrient transport across the placenta of lizards differing in placental complexity. Comparative Biochemistry and Physiology (Part A: Molecular \& Integrative Physiology) 127: 469-479.

Toft C.A., Trauger D.L. \& Murdy H.W. 1984. Seasonal decline in brood sizes of sympatric waterfowl (Anas and Aythya, Anatidae) and a proposed evolutionary explanation. Journal of Animal Ecology 53: 75-92.

VAN DEMme R., BAUWENS D. \& VERHEYEN R.F. 1989. Effect of relative clutch mass on sprint speed in the lizard Lacerta vivipara. Journal of Herpetology 23: 459-461.

WAPstra E. \& O’Reilly J.M. 2001. Potential 'costs of reproduction' in a skink: Inter- and intrapopulation variation. Austral Ecology 26: 179-186.

WAPSTRA E. \& SWAIN R. 2001. Reproductive correlates of abdominal fat body mass in Niveoscincus ocellatus, a skink with an asynchronous reproductive cycle. Journal of Herpetology 35: 403-409.

Williams G.C. 1966. Natural selection, the costs of reproduction, and a refinement of lack's principle. The American Naturalist 100: 687-690.

Wilson R.S. \& Boотн D.T. 1998. Effect of tail loss on reproductive output and its ecological significance in the skink Eulamprus quoyii. Journal of Herpetology 32: 128-131.

Wilson S.K. \& KNowles D.G. 1988. Australia's reptiles. NSW: William Collins Pty Ltd. 